\title{
"Dredging Method"- A Conservative Surgical Approach for the Treatment of Ameloblastoma of Jaw
}

\author{
SMA SADAT ${ }^{\mathrm{a}}$, M AHMED ${ }^{\mathrm{b}}$
}

\begin{abstract}
Summary:
Ameloblastoma is an aggressive benign odontogenic tumor of jaws with different clinical features and histologic patterns. The resection of mandible in growing young patient is associated with number of complications such as loss of jaw bone support, deformity, dysfunction and psychological distress even after reconstruction. An alternative conservative surgical procedure "Dredging
\end{abstract}

\section{Introduction}

Ameloblastoma is a locally invasive benign epithelial odontogenic tumor with different clinical characteristics and histological patterns. This tumor occurs mostly in the mandible ${ }^{1-10}$ and is slow growing and histologically benign in nature ${ }^{3-5,9}$. Resection of the mandible has been the principle treatment of ameloblastoma as the chance of recurrence is extremely high if it is treated by an inadequate procedure ${ }^{3-6,9,10}$. In most of the cases, the lesion is very extensive at the time of treatment because the tumor is painless and shows a slow and expansive growth. The resection of mandible including condyle and wide anterior region in growing young patient is associated with number of complications such as loss of jaw bone support, deformity, dysfunction and psychological distress even after reconstruction ${ }^{4,8}$.

The present paper introduces an alternative conservative procedure "Dredging Method" which eradicates the tumor and restores the normal contour and function of jaw in order to overcome these disadvantages. This article also describes the outline of the "Dredging Method" and presents the clinical feature of ameloblastoma treated by conservative procedures.

a. Dr. S. M. Anwar Sadat, BDS, MCPS, FCPS, MS(OMS), Lecturer, Dept. of Oral \& Maxillofacial Surgery, Dhaka Dental College \& Hospital, Dhaka, Bangladesh.

b. Professor Dr. Mohiuddin Ahmed, BDS, FCPS, PhD, Head, Dept. of Oral \& Maxillofacial Surgery, Dhaka Dental College \& Hospital, Dhaka, Bangladesh.

Address of Correspondence: Dr. S. M. Anwar Sadat, BDS, MCPS, FCPS, MS(OMS), Lecturer, Dept. of Oral \& Maxillofacial Surgery, Dhaka Dental College \& Hospital, Dhaka, Bangladesh. E-mail: an_sadat@yahoo.com, Mobile: 01711156023

Received: 3 August, 2009

Accepted: 16 March, 2011
Method" is a procedure which can eradicate the tumor as well as restore the normal contour and function of jaw. The procedure was followed in twenty four cases of histologically confirmed mandibular ameloblastoma in Bangladeshi patients, with recurrence of three cases in an average of two years follow up. The recurrent cases could be handled easily due to early detection in regular follow up.

(J Bangladesh Coll Phys Surg 2011; 29: 72-77)

Materials and Methods:

A retrospective study had been conducted on patients who attended department of Oral \& Maxillofacial Surgery in Dhaka Dental College \& Hospital and a private clinic, Dhaka from August 2001 to April 2008. The study included 24 patients who were selected by convenient sampling. All patients were diagnosed as ameloblastoma histologically and subsequently treated by “Dredging Method”.

"Dredging Method" is a conservative surgical procedure in which, after deflation and enucleation or only enucleation, repeated dredging is applied to accelerate new bone formation by removing out the scar tissue from the bony cavity. Deflation is used in large cystic lesion, where portion of the cystic wall, overlying bone and mucoperiosteum are removed in order to release intracystic pressure and facilitate the formation of a clear bony outline ${ }^{2,10}$. Enucleation is done after formation of clear bony outline; on the other hand enucleation is done directly in solid ameloblastoma. After enucleation the tumor is removed completely along with a portion of surrounding healthy bone, and then the bony cavity is kept open. The procedure is followed by repeated dredging out of the scar tissue that fill up the bony cavity and prevent the bone formation. Dredging is applied in 2-3 months interval to accelerate new bone formation and elimination of tumor cell nests. Histological examinations for all specimens are mandatory to ensure elimination of residual tumor cells and prevention of recurrence. In "Dredging Method" the follow up begins when the tumor cells are not identified in microscopic examinations of the scar tissues removed by 2 consecutive dredging. Continuous and regular follow up is an essential part of the treatment. 


\section{Outline of the "Dredging Method"}

For mainly cystic ameloblastoma

(Delation , Enuclaation and Dredging)

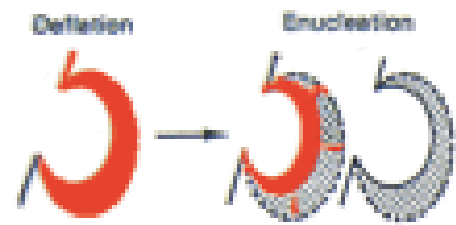

For mainly solid ameloblastoma (Enucleation and Dredging)

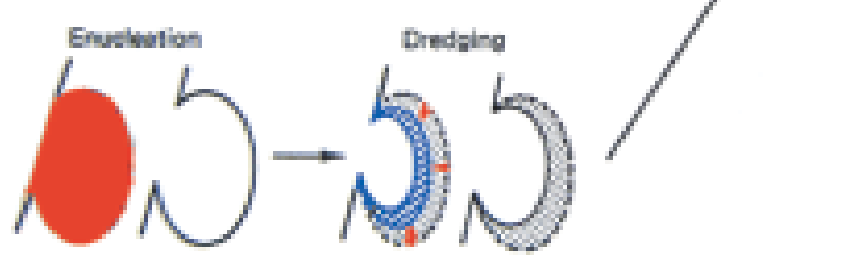
4 Tumor
Dow linsus
688
Pegonerating tome
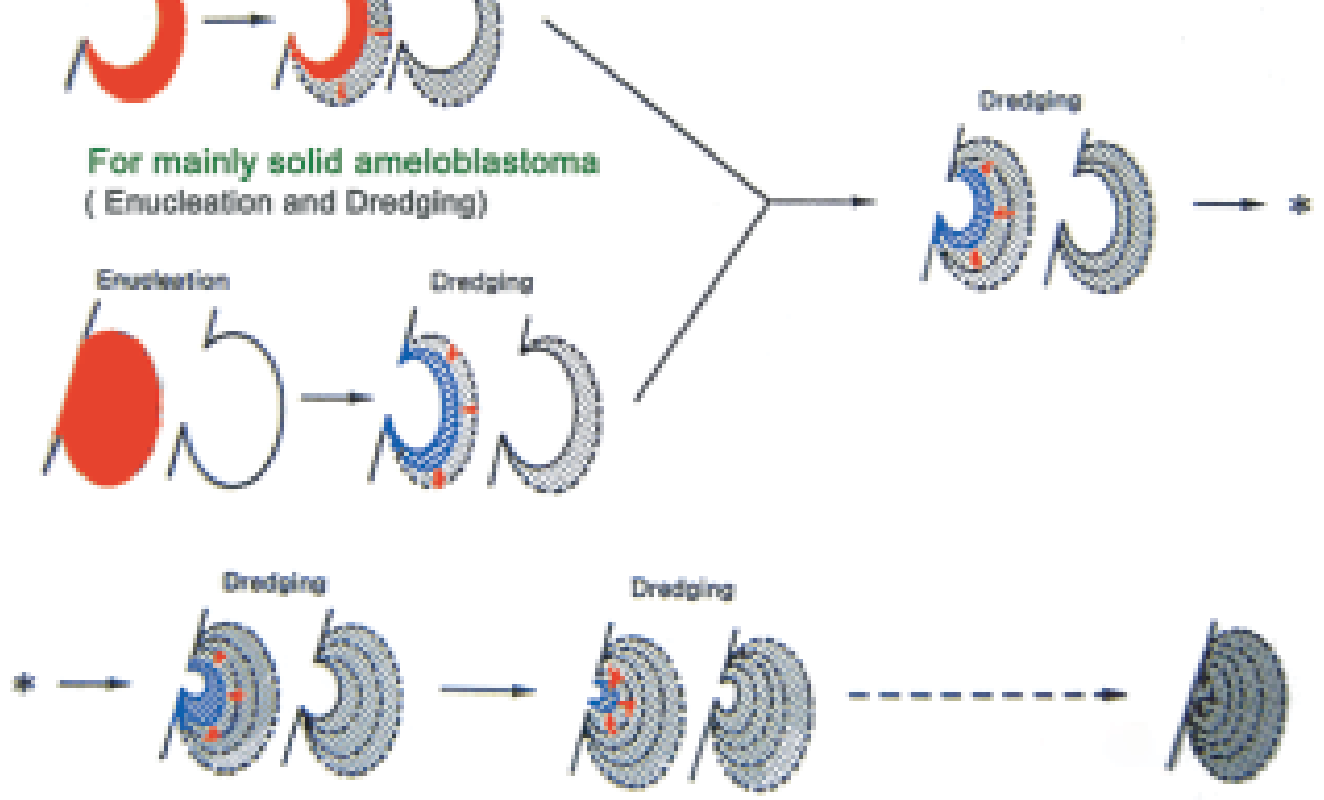

Outline of the "Dredging Method" Contd.

For ameloblastoma partly showing honeycombed appearance (Deflation, Enucleation, Selective marginal resection and Dredging)
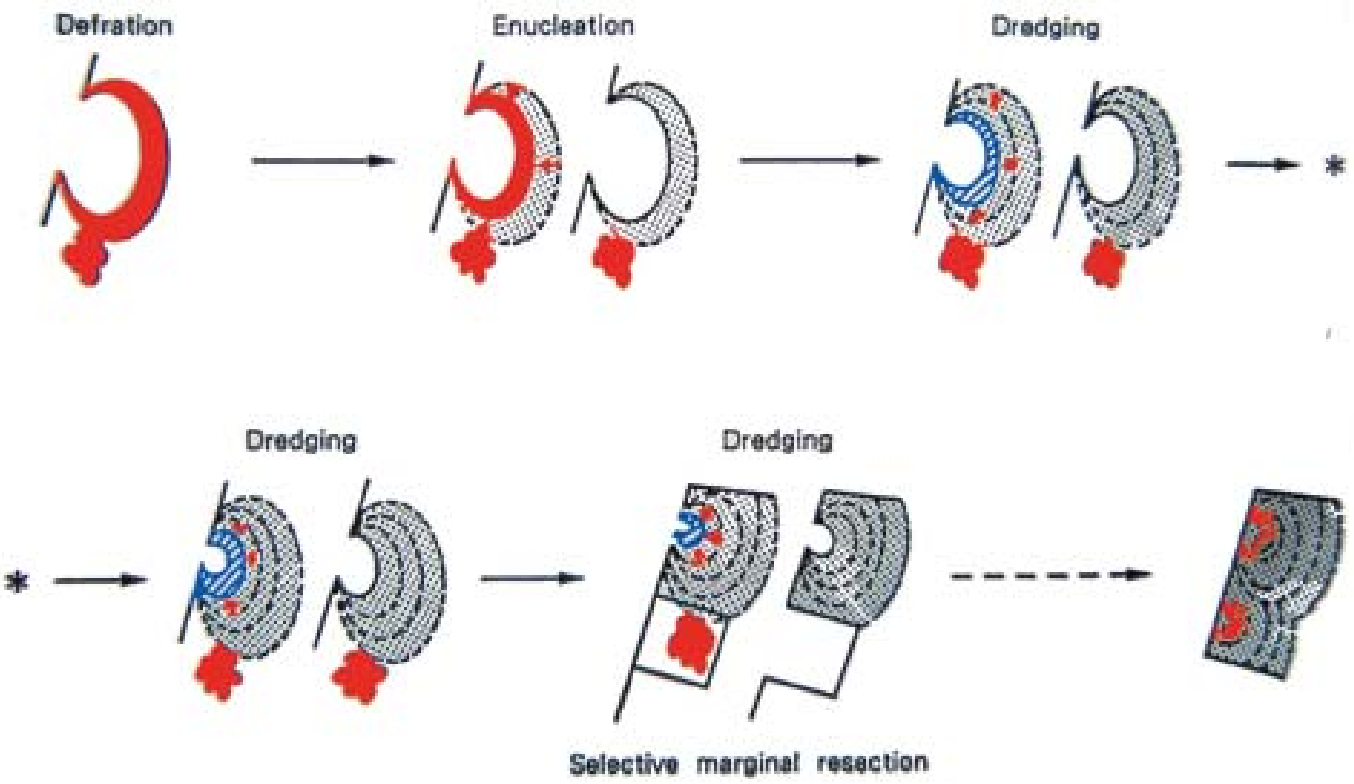
The above figures outlined the Dredging Method. In unicystic ameloblastoma deflation (marsupialization) is initially done to reduce tumor size which is followed by enucleation after adequate bone formation. Then dredging is applied repeatedly after every 2-3 months. In solid ameloblastoma, initial step is enucleation with removal of some peripheral bone followed by repeated dredging. In lesions having some honeycomb appearances in radiographs are treated by deflation, enucleation of total lesion with marginal resection of the area having honeycomb appearances. The total procedure ends up with repeated dredging to clear the tumor cells as well as to assist in sequential bone formation.

\section{Results:}

In the study period, a total of 88 cases of histologically diagnosed ameloblastoma were treated by different surgical approaches. Out of 88 cases 24 were treated by Dredging method and rest of the cases were treated by enucleation, marginal resection and segmental resection with or without condyle (Table-1). The male and female ratio of treated cases (by dredging method) was 5:7. Most of the cases (66.66\%) were within the age of 10-20 years (Table-2). In the Dredging patients, 18 cases $(75 \%)$ were treated by deflation, enucleation and dredging in which tumor cells were identified in dredged out tissues in 5 cases (Table-3) and recurrence was seen in 1 case (Table-4). 6 (25\%) out of 24 cases were treated by enucleation and dredging in which tumor cells were identified in dredged out tissues in 2 cases (33.3\%) (Table-3) and recurrence was seen in 2 cases (33.3\%) (Table-4).

\section{Table-I}

Treatment methods and no of cases treated (August 2001-April 2008)

\begin{tabular}{lc}
\hline Method of Treatment & No of Case \\
\hline Enucleation & 12 \\
Deflation Enucleation \& Dredging & 18 \\
Enucleation and Dredging & 06 \\
Marginal mandibular resection & 10 \\
Segmental mandibular resection & 12 \\
Mandibular resection including condyle` & 33 \\
\hline Total & 88 \\
\hline
\end{tabular}

Table-II

Age and sex distribution of patients underwent Dredging Technique $(n=24)$

\begin{tabular}{lccc} 
Age Range & Male & Female & Total \\
\hline $10-15$ & $4((16.7 \%)$ & $4(16.7 \%)$ & $8(33.3 \%)$ \\
$16-20$ & $3(12.5 \%)$ & $5(20.835)$ & $8(33.3 \%)$ \\
$21-25$ & $3(12.5 \%)$ & $4(16.7 \%)$ & $7(30.4 \%)$ \\
$26-30$ & $0(0 \%)$ & $1(04.250$ & $1(04.2 \%)$ \\
\hline Total & $10(41.7 \%)$ & $14(58.3 \%)$ & $24(100 \%)$ \\
\hline
\end{tabular}

Table-III

Clinical Evaluation by Identification of tumor cell nests in dredged out scar tissue

Treatment Method Identified Not Total

\begin{tabular}{lccc} 
& \multicolumn{3}{c}{ Identified } \\
\hline $\begin{array}{l}\text { Deflation, Enucleation, } \\
\text { Dredging }\end{array}$ & 5 & 13 & 18 \\
$\begin{array}{l}\text { Enucleation, } \\
\text { dredging }\end{array}$ & 2 & 4 & 6 \\
\hline
\end{tabular}

Table-IV

\begin{tabular}{lcccc}
$\begin{array}{l}\text { Clinical evaluation of cases treated by conservative } \\
\text { treatment methods }\end{array}$ \\
$\begin{array}{l}\text { Treatment } \\
\text { No }\end{array}$ & Recur & Lost FU Total \\
Recur & & & \\
\hline $\begin{array}{l}\text { Deflation, Enucleation, } \\
\text { Dredging }\end{array}$ & 14 & 1 & 3 & 18 \\
$\begin{array}{l}\text { Enucleation, } \\
\text { dredging }\end{array}$ & 4 & 2 & 0 & $6 \backslash$ \\
\hline \begin{tabular}{l} 
Total \\
\hline
\end{tabular} & 18 & 3 & 3 & 24 \\
\hline
\end{tabular}


Case - 1a: Radiographs show gradual bone formation and achievement of normal mandibular contour in sequential steps of "Dredging Method" in a 10 years old girl

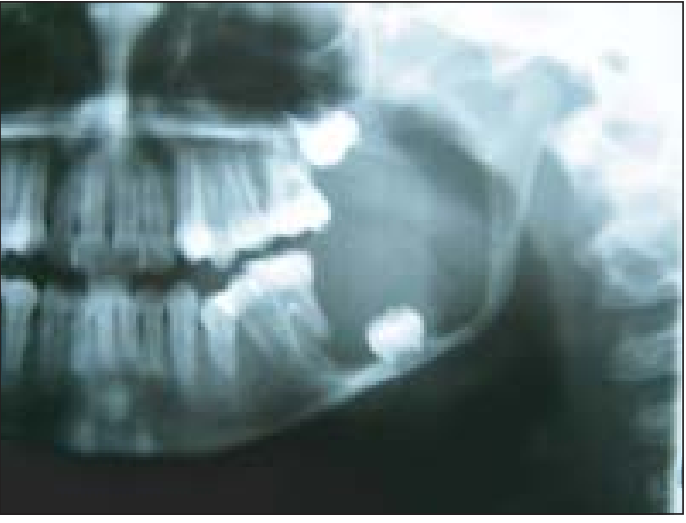

Fig-1: Orthopantomogram shows unicystic lesion in left ramus and adjacent body of mandible

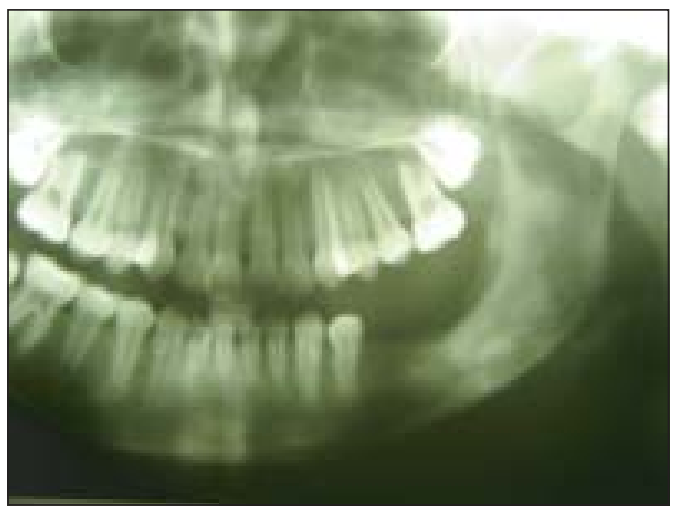

Fig-2: Orthopantomogram shows bone formation in left ramus and body of mandible 2 months after enucleation

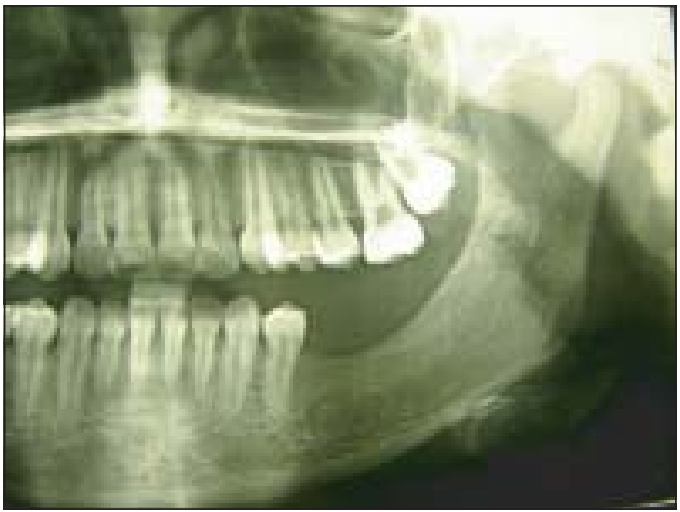

Fig-3: Orthopantomogram shows normal bone contour with cortical outline without evidence of recurrence 6 months after $2^{\text {nd }}$ dredging (12 months after enucleation)
Case - 1b: Clinical achievement of normal facial contour by "Dredging Method" in a 10 years old girl.

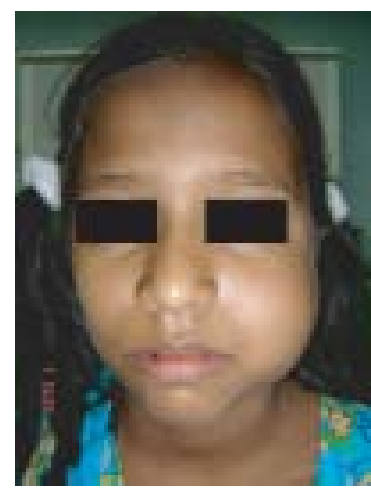

Fig-4: Photograph shows clinically evident expansile swelling (ameloblastoma) in left mandible

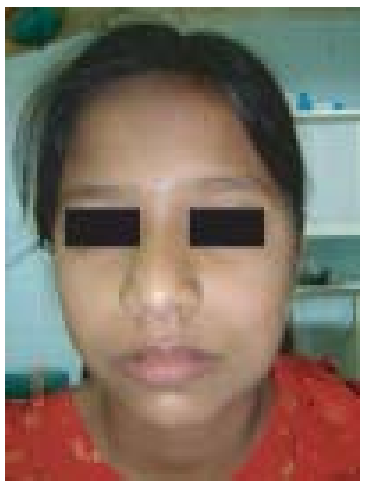

Fig-5: Photograph shows almost normal facial contour 2 months after enucleation

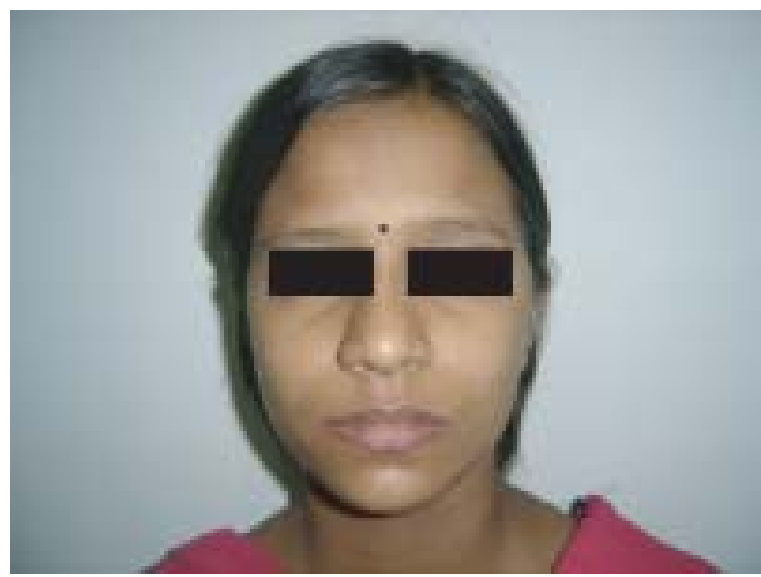

Fig.-6: Photograph shows normal facial appearance 12 months after enucleation 
Case-2: Orthopantomograms show gradual bone formation and achievement of normal mandibular contour in sequential steps of "Dredging Method" in a 13 years old boy.

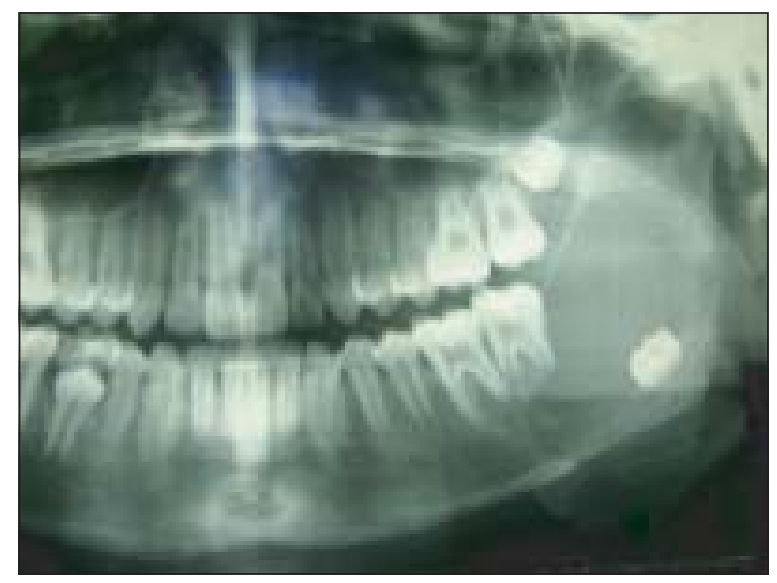

Fig.-7: Cystic lesion in left ramus of mandible

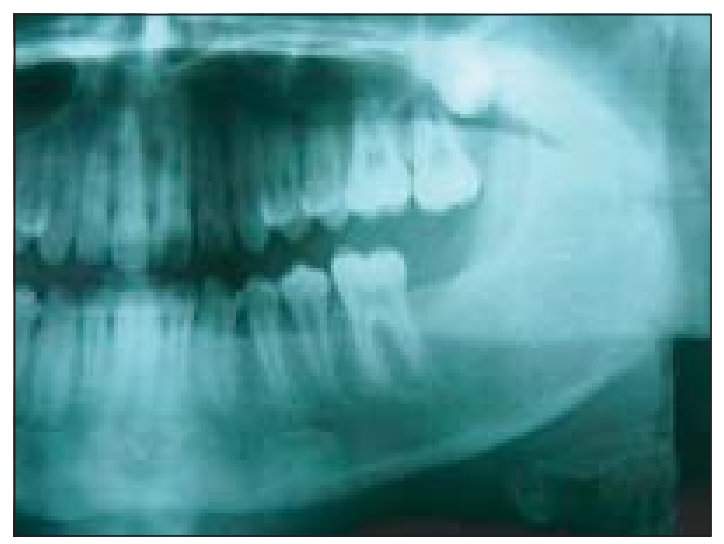

Fig.-8: Bone formation in ramus 6 months after enucleation

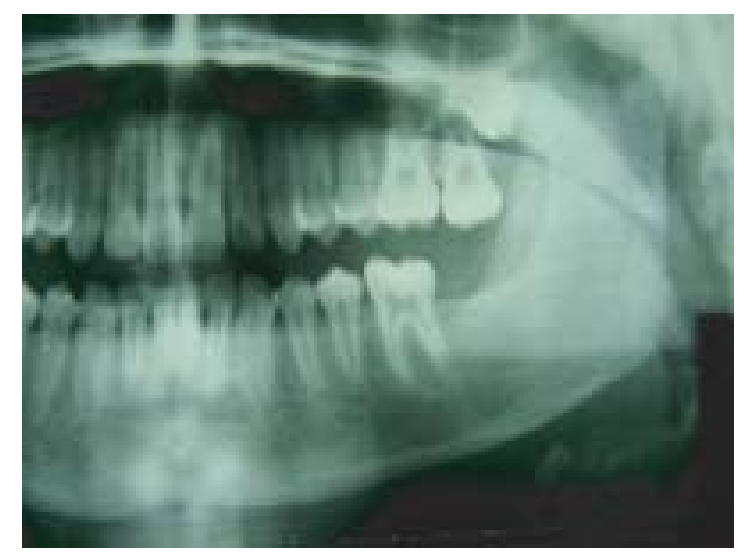

Fig.-9: Normal cortical outline with no evidence of recurrence in 20 months follow up

\section{Discussion:}

The contour of the face and oral cavity is directly related to the function and facial aesthetics. So, treatment of disease of the oral cavity becomes inadequate if it causes deformity of face. Deformity of the oral cavity causes functional inconvenience, aesthetic dissatisfaction and mental agony. So, the purpose should be - correction of disorder as well as to restore normal contour and function of jaw ${ }^{4,12}$. Considerations should be given to the age of patient, site, nature, extension of lesion. Dredging Method is considered to fulfill the purposes. It is seen that after deflation and enucleation the tumor cells are identified in the scar tissue within the bony cavity which is the cause of recurrence. So the scar tissue should be dredged out repeatedly to prevent the recurrence as well as to accelerate new bone formation. We got very low recurrence by this technique as also seen by other authors ${ }^{13,14}$. Follow up of these patients started when tumor cells were not identified in two consecutive microscopic examinations of dredged tissues. But often dredging is continued only for restoration of bony defect. For the treatment of ameloblastoma, a continuous and regular follow up is an essential part ${ }^{15,16}$. The authors recommended that this new technique should not be applied if the patient is not totally motivated for long term duration of follow up.

\section{Conclusion:}

A good result could be achieved in surgical treatment of ameloblastoma by systematic application of the technique -"Dredging Method". This procedure not only helps in acceleration of new bone formation at surgical areas but also helps in eliminating the tumor cell nests in the scar tissue. The facts indicate the essential role of dredging subsequent to deflation and enucleation. Ameloblastoma has usually variable clinical and histological patterns, and so the suitable treatment method from various procedures; i.e., deflation, enucleation, dredging, and different types of resection, should be chosen for successful outcome of this lesion.

\section{References:}

1. Sadat SMA, Ahmed M, Hossain KA, Bhuiyan RA, Rita SN. Ameloblastoma of Jaws: A Clinicopathologic Study of 24 Cases. The Journal of Bangladesh Orthopaedic Society 2005;20:29-33.

2. Sadat SMA, Haider IA, Hossain KA, Rita SN, Molla MR, Ahmed M. A Clinicopathologic Study and Management of Ameloblastomas in Dhaka Dental College and Hospital. Journal of Oral Health 2004;6:29-35. 
3. Kawamura M. A proposal for the treatment of ameloblastoma. Jpn. J. Oral Maxillofac. Surg. 1983;29:765.

4. Kawamura M, Kobayashi I, Inoue N. Dredging method-a new conservative treatment approach for cystic lesions and tumors of the jaw. Hokkaido J. Dent. Sci. 1988;9:104-106.

5. Kobayashi I, Kawamura M, Amemiya A et al. Histopathological pattern of ameloblastoma and choice of treatment method. J. Jpn. Soc. Oral Tumor 1985;3:45-48.

6. Lucas RB. Pathology of tumors of oral tissues, $4^{\text {th }}$ ed. Churchil Livingstone, London, 1984:pp. 31-56.

7. Shafer WG, Hine MK, Levy BM. A text book of oral pathology, $4^{\text {th }}$ ed. W.B. Saunders, Philadelphia, 1983: p.276.

8. Seldin HM. Conservative surgical treatment of ameloblastoma of the jaws. J. Oral Surg. 1944; 2:333-349.

9. Small IA, Waldron CA. Ameloblastoma of the jaws. O.S.,O.M.,O.P. 1955; 8:281-297.

10. Stout RA, Lynch JB, Lewis SR. The conservative approach to ameloblastomas of mandible. Plast. And Reconstr. Surg. 1963; 31:554-562.
11. Pandya NJ, Stuteville OH. Treatment of ameloblastoma. Plast. And Reconstr. Surg. 1972; 50:242-248.

12. Kawamura M. Treatment methods and related considerations for cystic lesions of jaw bone. Dental Diamond, Japan1983;8:42-43.

13. Kawamura M, Inoue N, Kobayashi I, Ahmed M. "Dredging Method"-a New Approach for the Treatment of Ameloblastoma. Asian J. Oral Maxillofac. Surg. 1991;3:8188.

14. Kawamura M, Inoue N, Kobayashi I, Ahmed M, et al. Ameloblastoma Treated by “Dredging Method"- Report of a Case. Asian J. Oral Maxillofac. Surg. 1991;3:89-93.

15. Muller H, Shootweg PJ. The ameloblastoma and its controversial therapeutic approach. J. Max. Fac. Surg. 1985; 13:79-84.

16. Waldron CA. Ameloblastoma in perspective. O.S., O.M., O.P. 1966;24:331-332 